\title{
INTRAOCULAR PRESSURE FOLLOWING PANCURONIUM
}

\author{
R. Brian Smith, M.B., B.S. and Napoleon Leā̄o, M.D. ${ }^{*}$
}

The NON-DEPolarizing muscle RelaXant D-TUbocurarine has been shown to lower intraocular pressure. ${ }^{1,2}$ A small dose of d-tubocurarine given before succinylcholine has been reported to abolish or reduce the rise in intraocular pressure caused by the latter. ${ }^{3}$ This investigation was done to compare the effect on intraocular pressure of pancuronium and succinylcholine in patients pretreated with a small dose of d-tubocurarine.

\section{METHOD}

Fourteen patients in ASA Physical Status I and II, aged from 17 to 70 years were studied during anaesthesia for minor operations on the head and neck. All were premedicated with pentobarbitone $2 \mathrm{mg} / \mathrm{kg}$ to a maximum of $150 \mathrm{mg}$, hydroxyzine $50 \mathrm{mg}$ and atropine $0.6 \mathrm{mg}$. Monitoring was by means of a precordial stethoscope, blood pressure measurements and cardioscope.

In the test group of eight patients anaesthesia was induced with sodium thiamylal $5 \mathrm{mg} / \mathrm{kg}$ followed by fentanyl $4 \mu \mathrm{g} / \mathrm{kg}$. After the loss of the lid reflex, postinduction intraocular pressure readings were made using a Schiotz tonometer with a $5.5 \mathrm{gm}$ weight. Pancuronium $0.1 \mathrm{mg} / \mathrm{kg}$ was administered and after two minutes the intraocular pressure was measured again and the trachea was then intubated. Intraocular pressure readings were made at one minute intervals for 10 minutes thereafter. Maintenance of anaesthesia was with 50 per cent nitrous oxide and 50 per cent oxygen.

In the control group of 6 patients, $3 \mathrm{mg}$ d-tubocurarine was first administered. Anaesthesia was then induced with sodium thiamylal $5 \mathrm{mg} / \mathrm{kg}$ followed by fentanyl $4 \mu \mathrm{g} / \mathrm{kg}$, as in the test group. After loss of the lid reflex, the post-induction intraocular pressure measurement was made. Succinylcholine $1.5 \mathrm{mg} / \mathrm{kg}$ was then given, 3 minutes after the d-tubocurarine. One minute later the intraocular pressure was measured and the trachea was intubated. The intraocular pressure was measured at one minute intervals for 10 minutes, and anaesthesia again maintained with 50 per cent nitrous oxide and 50 per cent oxygen.

Intraocular pressure measurements were made in both eyes except when a pathological condition existed in one eye. Arterial blood gas determinations were done on most patients after intubation. Topical anaesthesia of the larynx and trachea was not applied in any of the patients.

\section{RESULTS}

The readings of the intraocular pressure in the test group and control group are shown in Tables I and II respectively. They are compared graphically by

${ }^{*}$ Department of Anesthesiology, University of Pittsburgh School of Medicine and Department of Anesthesiology, Eye and Ear Hospital, 230 Lothrop Street, Pittsburgh, Pa. 15213. 

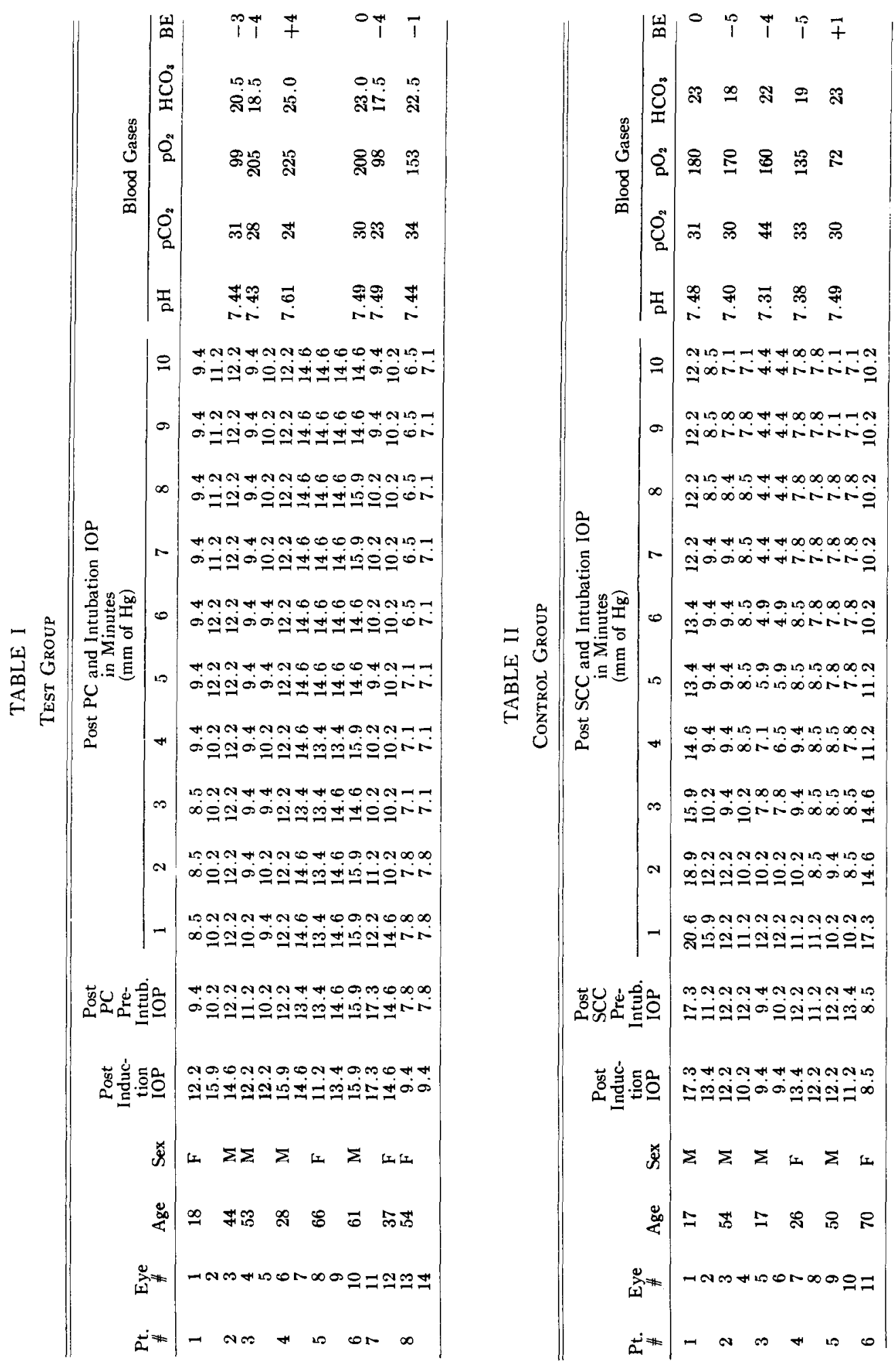


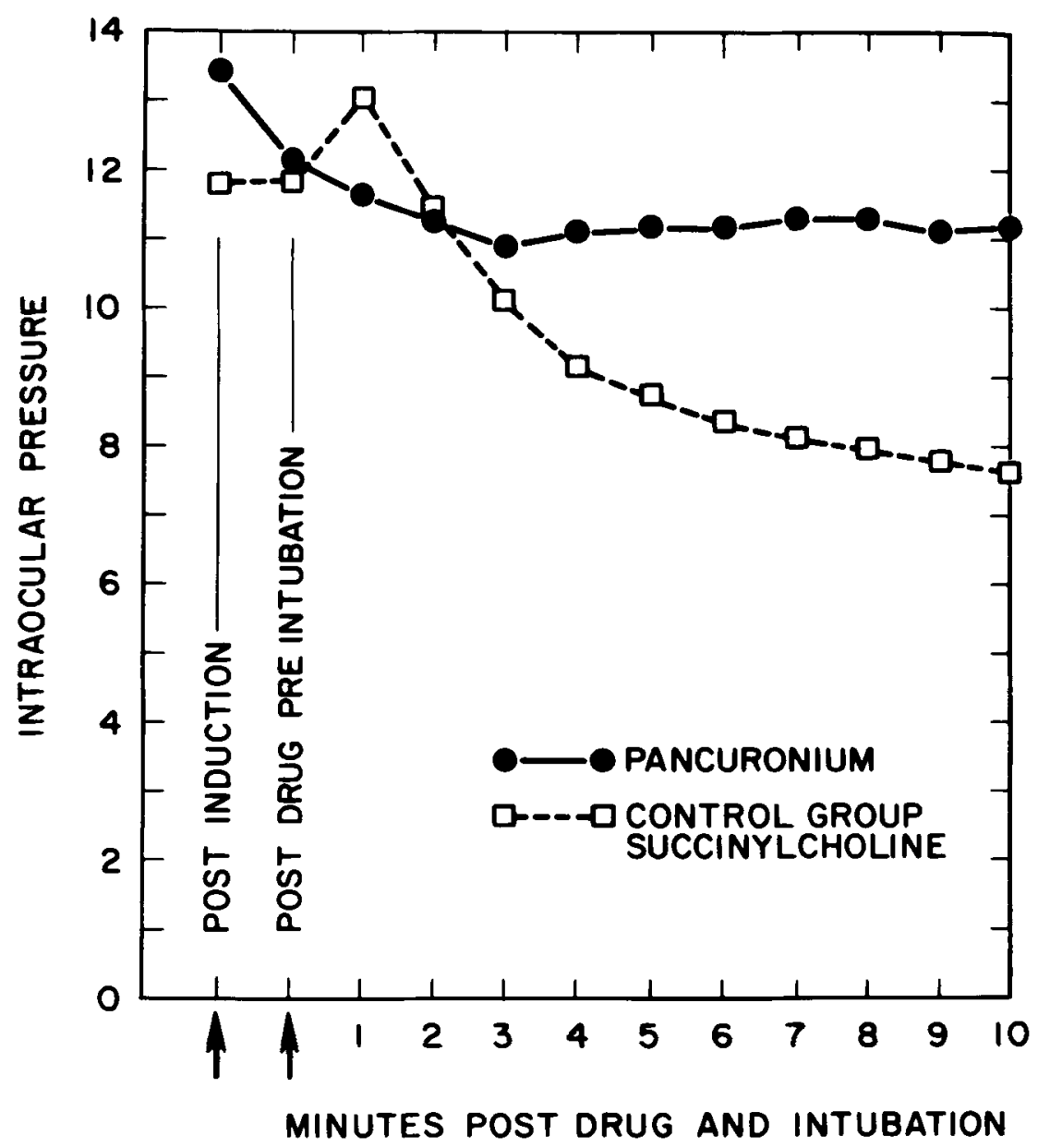

Figure 1. Comparison of intraocular pressure readings.

Figure 1. Blood gas determinations indicate that patients in both groups were adequately ventilated and oxygenated.

In the test group, the maximum drop in intraocular pressure occurred during the period from induction to three minutes post-intubation. In one patient there was an increase in intraocular pressure in both eyes and in seven there was a decrease in both eyes. This fall was statistically significant, $p<0.01$, while the rise in intraocular pressure in the one patient was not significant. Three minutes after intubation the intraocular pressure had become stabilized.

In the control group there was an increase in intraocular pressure from the time of induction to one minute post-intubation in 4 patients ( $\mathrm{six}$ out of seven eyes) and a decrease in two patients (four out of four eyes). However, the rise was statistically not significant. Five minutes after induction the intraocular pressure in the control group was significantly lower than the test group. 


\section{Comments}

Studies on the prevention of rise in intraocular pressure caused by succinylcholine by pretreatment with d-tubocurarine are inconsistent. For example, Wahlin $^{4}$ found that rise in intraocular pressure still occurred under these circumstances. Miller, Way and Duke-Elder ${ }^{3}$ on the other hand reported that increases in intraocular pressure after succinylcholine in both healthy and glaucomatous eyes were prevented by the intravenous administration of $3 \mathrm{mg}$ d-tubocurarine. The results in the control group in this study indicate that a rise in intraocular pressure caused by succinylcholine is not always prevented by pretreatment with d-tubocurarine. This is not surprising since Craythorne, Rottenstein and Dripps ${ }^{5}$ have shown that a rise in intraocular pressure may occur even after severance of all four rectus muscles. It should be pointed out that topical anaesthetic agents were not used on larynx and trachea, since this has been shown to influence the intra-ocular pressure following intubation after the administration of gallamine. ${ }^{6}$ The fall in intraocular pressure which was fairly consistent in both groups three minutes after intubation cannot be ascribed solely to the muscle relaxants. Barbiturate and hydroxyzine have both been shown to reduce intraocular pressure in man. ${ }^{7,8}$ All our patients also received fentanyl which may influence intraocular pressure in view of the fact that it has been demonstrated that morphine reduces it. ${ }^{9}$

Intubation following pancuronium using the technique described appears to be safe, as far as effects on intraocular pressure are concerned, prior to intraocular operations. Results indicate that pancuronium may be used safely in penetrating wounds of the eye.

\section{SUMMARY}

Intraocular pressure measurements were made in a test group of eight patients before and after the administration of pancuronium and tracheal intubation. Pressures were compared with those of a control group of six patients before and after the administration of succinylcholine, pretreated with d-tubocurarine, and followed by tracheal intubation.

A rise in intraocular pressure in one patient in the test group and in four patients in the control group one minute after tracheal intubation were statistically insignificant. The fall in intraocular pressure in the test group at three minutes after intubation was statistically significant.

Tracheal intubation following fentanyl, thiamylal and pancuronium appears to be safe, as far as effects on intraocular pressure are concerned, prior to intraocular operations. Results indicate that pancuronium may be used safely in penetrating wounds of the eye.

\section{RÉSUMÉ}

On a mesuré la pression intraoculaire chez un groupe de huit malades avant et après l'administration de Pancuronium ainsi qu'avant et après intubation endotrachéale.

Ces pressions furent comparées avec celles d'un groupe contrôle de malades 
avant et après l'administration de succinylcholine. Ces malades avaient reçu au préalable une dose de d-tubocurarine et avaient été intubés par la suite.

L'augmentation de la pression intra-oculaire chez un malade du premier groupe et chez quatre malades du groupe de contrôle, une minute après l'intubation endotrachéale, ne fut pas significative au point de vue statistique.

Par contre, la chute de la tension intra-oculaire chez le premier groupe trois minutes après intubation endotrachéale fut significative.

Donc, avant une chirurgie intra oculaire, l'intubation endotrachéale à la suite de l'administration de Fentanyl, thiamylal et Pancuronium nous apparaît sûre en ce qui concerne ses effets sur la pression intraoculaire. Les résultats indiquent que la pancuronium peut être utilisé avec sécurité dans les cas de plaies pénétrantes de l'œil.

\section{REFERENCES}

1. Agarwal, L.P. \& Mathur, S.P. Curare in ocular surgery. British J. Ophthal. 36: 603 (1952).

2. Colle, J., Duke-Elder, P.M., \& Duke-Elder, W.S. Studies on the intraocular pressure. J. Physiol. (London) 71: 1 (1931).

3. Miller, R.D., WAY, W.L., \& HICKEY, R.F. Inhibition of succinylcholine-induced increased intraocular pressure by nondepolarizing muscle relaxants. Anesthesiology 29: 123 ( 1968 ).

4. Wamlin, A. Clinical and experimental studies on effects of succinylcholine. Acta Anaesth. Scand. Suppl. 5: 1 (1960).

5. Craythorne, N.W.B., Rottenstein, H.S., \& Dripps, R.D. The effect of succinylcholine on intraocular pressure in adults, infants and children during general anesthesia. Anesthesiology 21: 59 (1960).

6. Goldsmith, E. An evaluation of succinylcholine and gallamine as muscle relaxants in relation to intraocular tension. Anesth. Analg. 46: 557 (1967).

7. Everett, V.G., Wex, E.K., \& Vienis, C.Y. Factors in reducing ocular tension prior to the intraocular surgery. Trans. Amer. Acad. Ophthal. Otolaryng. 63: 286 (1959).

8. Farmatt, O., Buttermore, C.W., Taylor, F.H., \& MCCaslin, M.F. Intravascular pressure changes following intravenous hydroxyzine in man. Amer. J. Ophthal. 64: 143 (1967).

9. LEOPOLD, I.H. Effect of intramuscular administration of morphine, atropine, scopolamine and neostigmine on the human eye. Arch. Ophthal. 40: 285 (1948). 